\title{
Odlišné světy učitelů a rodičů: interakce s rodiči jako zdroj stresu učitele ${ }^{1}$
}

\author{
Veronika Pavlas Martanová a , Olga Konůpková ${ }^{b}$ \\ ${ }^{a}$ Univerzita Karlova, Pedagogická fakulta, Katedra psychologie \\ ${ }^{\mathrm{b}} \mathrm{ZŠ}$ Vladislava Vančury, Praha
}

Redakci zasláno 4.1.2019 / upravená verze obdržena 31. 5. 2019/

/ k uveřejnění přijato 1. 6. 2019

\begin{abstract}
Abstrakt: Cílem této empirické studie je popsat, jaké faktory identifikovali učitelé základních škol jako zdroj stresu v kontaktu s rodiči. V první části mapuje výzkumné aktivity v oblasti učitelského stresu v posledních desetiletích. Ve druhé části se zabývá metodologií výzkumu - tematickou analýzou dat a popisem vzorku respondentů (45 rozhovorů z 12 zŠ). Ve třetí části jsou prezentovány výsledky šetření, čtvrtá část je věnována diskusi a pátá část praktickým doporučením. Studie naznačuje, že na pozadí teorie stojí učitelská kauzalita potíží dítěte (učitel viní rodiče - jedná se o obranu proti vlastnímu stresu). Centrální kategorií zdroje stresu je vzájemná komunikace a některé její aspekty: míra komunikace, její obsah a směr, vyváženost sil při komunikaci a její dokumentace. „In vivo“ pak vzniká termín „,rodičc-prudič“, v němž se násobí nevhodná míra (příliš často), obsah (emocionálně a kriticky) i směr komunikace (od rodiče ke škole) s nežádoucí podporou ze strany institucí a nutností vše dokumentovat. „Rodič-prudič“ je koncentrátem učitelského stresu. Většina námi popisovaných stresorů v komunikaci s rodiči se objevuje již ve studiích publikovaných po roce 2000, př́nos studie je spíše v popisu vzájemného vztahu jevủ a jejich prohlubování. Jsou formulována praktická doporučení: témata vztah rodiny a školy a komunikace v zátěžových situacích pro pregraduální studium, zavádění supervize do škol a systémová podpora učitelů.
\end{abstract}

Klíčová slova: učitel, stres, komunikace s rodiči, syndrom vyhoření

Cílem naší empirické studie je popsat, jaké faktory identifikovali učitelé základních škol jako zdroje stresu v oblasti kontaktu s rodiči. Článek vznikl jako jeden z výstupů výzkumu Učitelské vyhoření - institucionální, vztahové a intrapsychické faktory (GA16-21302S). Domníváme se, že zájem o učitelské prožívání stresu a pojmenování rizik může být velmi užitečným odrazovým

1 Článek vznikl jako jeden z výstupů výzkumu Učitelské vyhoření - institucionální, vztahové a intrapsychické faktory podpořeného Grantovou agenturou ČR (GA16-21302S); Katedra psychologie Pedagogické fakulty UK v Praze. Děkujeme tímto Grantové agentuře ČR za podporu. 
můstkem pro posilování prevence vyhoření učitelů, a tím i nástrojem zkvalitňování našeho školství. Doufáme, že náš příspěvek pomůže poodhalit, co učitele ve škole nejvíce stresuje $\mathrm{v}$ komunikaci s rodiči a jaký typ rodiče či rodičovského chování je pro učitele nejnáročnější. $V$ závěru naší studie se pak pokusíme zformulovat některé výzvy pro české školství, které vyplývají ze zjištěných dat.

\section{Teoretická východiska}

Pro potřeby naší studie definujeme stres jako reakci na stresor, tedy jako stav, který vzniká v důsledku působení zátěžových faktorů a podněcuje komplexní odpověd' zahrnující fyzické i psychické projevy (Seley, 1966). Stres vnímáme zejména v jeho negativním rozměru jako vnitřní stav člověka, který je něčím přímo ohrožován nebo takové ohrožení očekává a současně se domnívá, že jeho obrana proti nepříznivým vlivům není dostatečná (Křivohlavý, 1994). Stres je souhrn reakcí na vychýlení jedince z rovnováhy mezi přijímanou a vydávanou energií (Fink, 2010).

České i zahraniční studie v posledních desetiletích odkryly mnoho různých zdrojů učitelského stresu. Někteří autoři se pokusili rozdělit tyto zdroje do různých oblastí (např. Holeček, 2001; Kyriacou, 2004; Mlčák, 1999; Paulík, 1998). Ukazuje se, že zdroje stresu učitelů pocházejí z více směrů. Mezinárodní výzkum rozlišil šest hlavních stresorů: nedostatečné finanční ohodnocení a nízká prestiž povolání, konflikt rolí a profesní dilemata, časový tlak, problematické chování žáků, vztahy s nadřízenými, př́liš početné třídy (Brackett et al., 2010).

V českém prostředí bylo u učitelů základních škol identifikováno sedm stresorů: pracovní přetížení (zahrnuje časovou tíseň i nadbytečnou administrativu), vedení školy s nadřízenými orgány (zahrnuje nejen vedení školy, ale také požadavky obecního úřadu nebo Českou školní inspekci), problémoví žáci, neuspokojená potřeba seberealizace (frustrace z nedocenění společností a nízkého finančního ohodnocení), problémoví rodiče, nevyhovující pracovní prostředí školy, problémoví kolegové (Holeček, 2001). Tyto stresory se navíc často kombinují (např. problémový žák a problémový rodič). Nejvíce zatěžující je pro učitele vysoká míra pracovního stresu v kombinaci se stresem v soukromém životě, např. v př́ípadě rodinných problémů (Kohoutek \& Řehulka, 2011).

Na základě výše uvedeného je možno stanovit tři skupiny stresorů: (1) vztahy s dětmi, rodiči a kolegy, (2) konkrétní pracovní podmínky a (3) postavení učitelské profese ve společnosti (Smetáčková, Vondrová, \& Topková, 2017). 
V mnoha studiích je sledována jako zřetelný zdroj profesní nespokojenosti, pocitů vyčerpání, zdravotních problémů a odchodu ze školství do jiného zaměstnání právě emočně náročná komunikace s rodiči, konflikty s rodiči a malá podpora od rodičovské veřejnosti (Farber, 1982a; Lasky, 2000; Urbanovská, 2011, ad.). Nedostatečnou spolupráci s rodiči jako významný zdroj stresu učitele uvádí rovněž Štětovská a Skalníková (2004), v zahraničí např. Keyes (2002). Lasky se zaměřil na pozitivní a negativní zkušenosti a emoce učitelů při interakcích s rodiči. $\mathrm{Z}$ výsledků vyplynulo, že učitelé se cítí pozitivně v okamžiku, kdy vnímají rodiče jako zodpovědné, respektující jejich odborný úsudek a podporující jejich výukové snahy. Negativní pocity vyvolává, když rodiče nedodržují normy dané instituce, chovají se nevhodně a zpochybňují autoritu učitele (Lasky, 2000). Hargreaves a Lasky (2004) později popsali, že zdrojem pozitivních emocí pro učitele je zejména uznání a vděčnost. Naopak prožívají negativní emoce, když rodiče zpochybňují jejich rozhodnutí, útočí na jejich profesionalitu, odbornost nebo když věří více verzi svého dítěte než verzi učitele. Zdrojem frustrace je také to, když rodiče nespolupracují a učitelé nemají žádnou moc je ke spolupráci přimět. Rodiče působí na dítě a jeho hodnoty, čímž mohou ztěžovat práci učitele, pokud se hodnoty obou systémů liší. Takový učitel má obtížnou cestu k žákovi a rovněž se potýká se svými emocemi vzteku a znechucení vůči nestarajícímu se rodiči.

Výzkum stresu u učitelů je velmi významně provázán s fenoménem výzkumu syndromu vyhoření (Urbanovská, 2011). Dlouhodobý stres může vést ke vzniku syndromu vyhoření, a to rovněž mezi vyučujícími (Kebza \& Šolcová, 2008; Marek, Schaufeli, \& Maslach, 2017). Syndrom vyhoření chápeme jako multidimenzionální konstrukt. Maslachová identifikovala tři dimenze vyhoření - emocionální vyčerpání, depersonalizaci a sníženou výkonnost (Maslach, Jackson, \& Leiter, 1996). Shirom a Melamed (2006) vyčlenili tři částečně odlišné dimenze - fyzické, emocionální a kognitivní vyčerpání.

Stres učitelů a syndrom vyhoření odlišil jako dvě oddělené koncepce již Farber (1982a). Ve svém výzkumu provedeném na 700 amerických školách došel k závěru, že významným faktorem, který vede k vyhoření učitelů, je nedostatek podpory vedení a nedostatek rodičovské podpory. Ve výzkumu uvedlo $67 \%$ učitelů, že vůbec nikdy nebo pouze zřídka mají pocit, že rodiče jejich práci usnadňují. 80 \% učitelů není nikdy nebo jen zř́́dka spokojeno s postavením učitelů ve společnosti. Zatěžující se ukázalo i nadměrné papírování, neuspokojivé administrativní porady a nedostatek př́ležitostí k rozvoji. 
Jako nejvýraznější stresory vedoucí k syndromu vyhoření v ČR bez ohledu na pohlaví byly identifikovány: nadměrný pracovní shon a zahlcení úkoly, nedostatečné finanční ohodnocení a nespokojenost se školskou politikou (Urbanovská \& Kusák, 2005; Urbanovská, 2011). Jako stále významnější se ukazuje vztah mezi syndromem vyhoření a copingovými strategiemi učitelů (Smetáčková, Vondrová, \& Topková, 2017).

\section{Metodologie}

Článek prezentuje závěry analýzy části dat z výzkumu Učitelské vyhoření - institucionální, vztahové a intrapsychické faktory realizovaného na základních školách v ČR. Tento širší výzkum mapoval kvantitativně i kvalitativně míru projevů vyhoření u učitelů a hledal faktory, které mohou přispívat $\mathrm{k}$ jeho vzniku, či naopak k ochraně před ním; jeho závěry byly publikovány samostatně (Ptáček et al., 2018; Smetáčková et al., 2018). Výzkum sledoval mimo jiné i které faktory učitelé označují za zdroje svého pracovního stresu. Naše studie navazuje na již publikovaný výzkum. Kvalitativní data jsme použili k podrobnějšímu zkoumání zdrojů stresu u učitelů a konkrétně jsme se zaměřili na významný stresor, tj. na rodiče a komunikaci s nimi.

Celkový výzkum podpořený GA ČR byl tvořen dvěma částmi. První část představovalo online dotazníkové šetření, kterého se zúčastnilo 2394 vyučujících základních škol. Druhou částí byla série 12 př́ípadových studií základních škol. Menší část škol byla požádána o spolupráci na základě předchozího kontaktu, větší část škol vstoupila do výzkumu na základě souhlasu po náhodném oslovení.

Srovnání výsledků dotazníku mezi školami, kde probíhaly případové studie, a ostatními zúčastněnými vyučujícími ukázalo, že se jedná o školy mírně nadprůměrné zejména z hlediska profesní spokojenosti vyučujících. Tento fakt může mít vliv na prezentovaná data a je zároveň limitem této studie.

V našem vzorku je 5 škol z velkých měst, 3 školy ze středního města, 2 školy $\mathrm{z}$ malého města a 2 školy z vesnice. Materiálem pro analýzu byly rozhovory s učiteli sledovaných škol. Celkem se jedná o 45 pořízených rozhovorů, každý trval zhruba 50 minut; učitelé vyslovili svůj souhlas s použitím dat. Rozhovory byly realizovány s učitelkami a učiteli, kteří ve své škole skórovali jako ti, u nichž bylo identifikováno nejvíce či nejméně projevů syndromu vyhoření dle Shirom-Melamedovy škály vyhoření (dále jen SMBM) (Ptáček et al., 2018; Shirom \& Melamed, 2006) v rámci širšího dotazníkového online šetření. Kontaktovali jsme učitele umístěné na krajních pozicích 
ve výsledcích SMBM ve své škole. Počet spíše spokojených a spíše vyhořelých ve vzorku je vyrovnaný. Počet mužů a žen kopíruje rozložení v učitelské populaci na ZŠ (85 \% žen, $15 \%$ mužů). Vzorek tvoří běžní učitelé bez podílu na vedení školy. Rozhovory byly polostrukturované. Předem jsme stanovili okruh témat, kterých se v rozhovoru chceme dotknout tak, abychom co nejkomplexněji postihli všechny stránky školy, které mohou mít vliv na profesní spokojenost. Pořízené rozhovory byly přepsány, nespisovnost výroků drobně korigována.

Metodologicky byl náš postup založen na metodě tematické analýzy (Braun \& Clarke, 2006; Plichtová, 1996) s využitím postupů a technik metody zakotvené teorie, která zahrnuje otevřené a selektivní kódování (Strauss \& Corbin, 1999). Tematická analýza představuje postup vyhledávání obsahových vzorců v datech kvalitativní povahy a je platnou metodou v širokém rámci kvalitativních analytických metod (Braun \& Clarke, 2006). Přináší nejen důkladné uspořádání a popis dat, ale umožňuje také interpretovat nejrůznější aspekty výzkumného tématu. Tématem se pak rozumí vzorec, objevený v datech, který data popisuje, organizuje a též interpretuje (Boyatzis, 1998). Ve výběru a prezentaci témat hraje aktivní roli výzkumník, jenž po celou dobu kódování dat i extrakce témat stále vstupuje do dialogu s výzkumným materiálem a reflektuje analytický proces jako takový. V našem př́ípadě proběhlo nejprve otevřené kódování získaných rozhovorů, které zahrnovalo extrakci všech výroků, které se nějak dotýkaly zdrojů stresu u učitelů a následně těch stresorů, které jsou nějakým způsobem spojeny s rodiči. Následovalo seskupování označených kódů do dílčích kategorií, které nám dále umožnilo identifikovat základní tematické okruhy. ${ }^{2}$

2 Tematická analýza byla realizována v těchto šesti krocích:

1. Seznámení se s daty: opakované čtení, transkripce dat (v rámci většího celku projektu GAČR).

2. Vytváření otevřených kódů: celý datový soubor byl okódován širším výzkumným týmem.

3. Identifikace témat: probíhalo slučování kódů do obecnějších témat, aby bylo možné rozlišit různé úrovně témat, pro potřeby této studie identifikovány kategorie propojující kódy „zdroje stresu“ a "rodiče“.

4. Revize témat: sloučení témat, generace tématu vzájemné komunikace rodiče a učitele při zachování vnitřní homogenity a vnější heterogenity, ověřena výpovědní hodnota tématu.

5. Definování a pojmenování témat: identifikování „jádra“ tématu - popis backgroundu tématu v učitelské atribuci, popis aspektů komunikace a jejich významu ve vztahu ke stresu učitele a definování kódu in vivo „rodič-prudič“ jako esence učitelského stresu. Téma je detailně popsané a vtažené k celkovému „př́íěhu“ - k odpovědi na výzkumnou otázku Co učitelé označují jako zdroj stresu v kontaktu s rodiči.

6. Zpracování studie/článku. 
V analýze jsme pracovali s tématy explicitně vyjádřenými. Vzhledem ke kvalitativní povaze dat a též k povaze analýzy poskytují jednotlivá témata rozsáhlý objem citací, který v textu využíváme pro lepší přiblížení problému. Citace z rozhovorů jsou psány v uvozovkách. Pokud uvedené citace obsahovaly jména, nahradili jsme tato jména jmény smyšlenými.

\section{Výsledky}

Při prezentaci výsledků využíváme následující uspořádání (viz obrázek 1). V úvodu bude prezentována učitelská kauzální atribuce potíží dítěte ve vztahu $\mathrm{k}$ rodině, která tvoří významný background, pozadí našeho tématu. Následně budou prezentovány různé aspekty komunikace rodiny a školy, které se ukázaly jako zdroje stresu (míra, obsah a směr komunikace, rovnováha či nerovnováha sil v komunikaci a nutnost dokumentace). V závěru prezentace dat představíme „rodiče-prudiče“ jako kód „in vivo“, který ztělesňuje kumulaci a násobení stresu učitele.

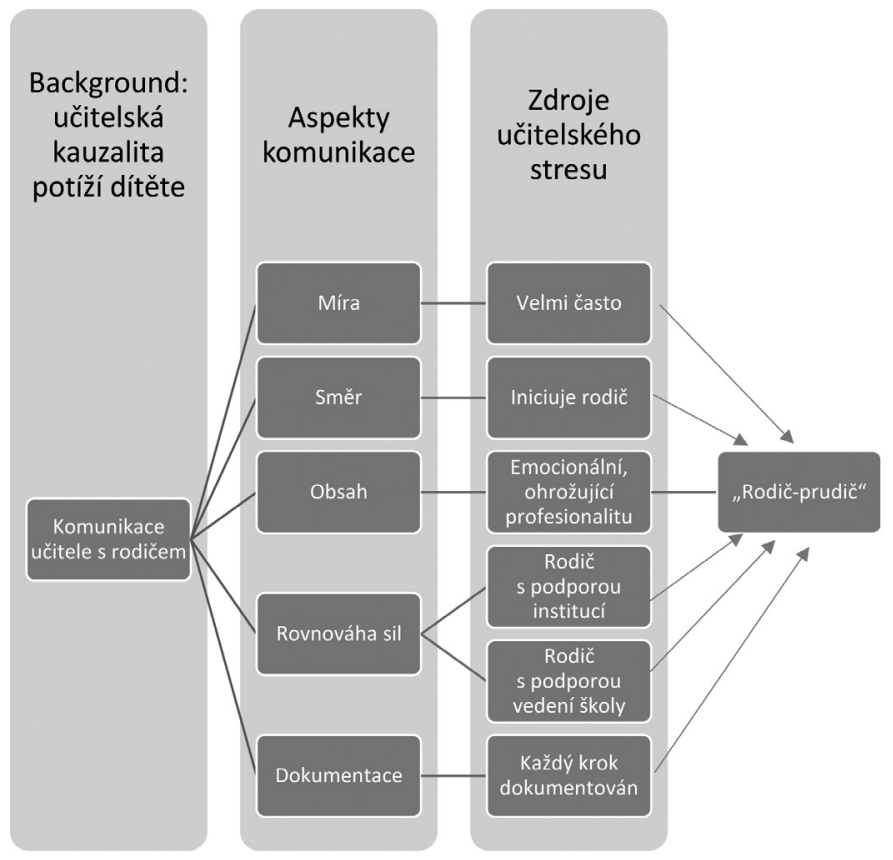

Obrázek 1. Grafický přehled prezentovaných témat. 


\subsection{Učitelská kauzalita potíží dítěte jako pozadí učitelského vnímání}

Učitelé ř́kají, že děti jsou odrazem či obrazem svých rodičů a je na rodiči, jak bude dítě ve škole prospívat. Otisk rodiny vidí ve stylu výchovy, pojetí norem a míry, do jaké se rodina dítěti věnuje a jak ho pro školu motivuje: „Ano, to je ten problém těch rodičů. Začíná to u těch rodičů, ty děti jsou jenom obrazem svých rodičů, prostě to tak je."

Pokud učitelé hovoří o dětech problémových, pak se zdá, jako by samo problematické dítě možná nebylo tím pravým problémem. Problémem z učitelovy perspektivy je často rodič. Učitel vidí zdroj stresu a příčiny či vinu spíše na straně rodiče než dítěte. Místy mají učitelé dokonce tendenci dítě omlouvat, nezlobí se na dítě (jako by zloba na dítě byla do určité míry učitelským tabu), nýbrž na rodiče jako zdroj potíží, nevychovanosti dítěte: „Já si myslím, vždycky ř́íkám, že děti jsou odraz svých rodičů a někdy, když vidíme některé nevychované rodiče, tak pak se nikdy nemůžu zlobit na děti.“

Ukázalo se, že učitelé se snaží získat informace o rodině problematického dítěte, at' již komunikací s jeho rodiči nebo se svými kolegy. Postupně si skládají mozaiku o rodině a jejím fungování, př́íp. nefungování. K poznání dítěte slouží také zprávy od odborníků, které rodiče škole ve velké míře poskytují. Zdrojem informací bývají i sociální sítě. Učitelé využívají dostupná data a dělají si svůj „obrázek“. Na základě získaných informací se u učitele objevuje tendence soucítit s dětmi z nefunkčních či jinak problematických rodin. Někdy však prožívají také vztek a únavu.

Je tady kluk jeden, to jsem v životě nezažila za ty léta, co učím, doufám, že to ani nezažiju, to je prostě dítě s ADHD a zároveň nevychovaný ani ne fracek, parchant spíš. Prostě něco neskutečného. Je to samozřejmě daný rodinou, rodinnými poměry.

Oba př́iklady z výše uvedených výpovědí jsou dle tvrzení učitelů provázeny zvýšeným stresem.

Jako odborník v pomáhající profesi si učitel vysvětluje chování dítěte jako následek výchovy v rodině. Nevidí však dítě samotné, nýbrž aktivně pátrá po kontextu. Pohled učitelů je z velké části založený na tom, že dítě je utvářeno svým prostředím. 0 dědičnosti či vrozenosti se učitelé v rozhovorech nezmiňovali. Učitelé jsou tedy laděni spíše empiricky, ale zásadní vliv přisuzují rodině, jejímu působení - výchově, svůj vlastní (taktéž empirický) vliv na dítě vidí jako limitovaný. Z rozhovorů s učiteli jednoznačně vyplývá, že 
sami učitelé považují často za větší problém rodiče problematického dítěte než dítě samotné. Je-li dítě problematické, učitel se na rodinu zlobí, obviňuje ji a je tímto faktem stresován. Někdy se zdá, že rodina mu kazí jeho práci.

Tuto kauzální atribuci vidíme jako jeden z prostředků, kdy se učitel snaží pojmenovat příčinu potíží, aby snížil svůj stres, jemuž je vystaven při pocitech bezmoci a frustrace. Dá se říci, že se jedná o jeden z obranných mechanismů proti stresu či o učitelskou copingovou strategii.

Co přesně ve vztahu s rodiči učitele stresuje? Centrální kategorií, která se jeví jako zdroj stresu, je vzájemná komunikace učitele a rodiče a některé její aspekty: míra komunikace, její obsah a směr a vyváženost sil při komunikaci.

\subsection{Míra komunikace}

Učitelé hovoří o komunikaci s rodinou, která může být zdrojem stresu. Specifika a vyšší nároky pak nese komunikace s rodinou dítěte problémového.

Učitelům na jedné straně vadí, když rodiče problémového dítěte vůbec nekomunikují a nechodí na třídní schůzky ani konzultace:

Co mě třeba překvapilo, že moc rodiče nechodí na ty konzultace, a ty tř́dní schůzky, většinou to bývá tak, že problémových žáků rodiče nepřijdou, těch takových, kteří jsou jedničkáři, dvojkaři přijdou.

Na straně druhé je zdrojem stresu i situace, kdy rodiče komunikují s učitelem velice často a určitým pro učitele nepřijatelným způsobem. Obsah učitelských výpovědí na toto téma by se dal shrnout bonmotem: Špatný rodič se vůbec nezajímá. Nebo se naopak zajímá moc. Je v tom jistý paradox - učitelé odsuzují ty rodiče, kteří se o děti nezajímají a se školou nekomunikují, a zároveň mají stejně negativní vztah k těm rodičům, kteří dělají pravý opak.

Učitelům vadí čas, který stráví dohadováním s rodiči ve chvíli, kdy se jedná o neustále se opakující stížnosti a spory tzv. věčně nespokojeného rodiče. Učitel má pocit, že v první řadě má vzdělávat a vychovávat děti, a je rozladěný, když mu rodič z času dedikovaného na tento pracovní úkol ubírá:

Pro mě je to protivný, mě to s nimi nebaví a nebaví mě si s nimi hrát tu hru na důležitost. Já tady nejsem od toho, abych jim ukázala, že jsem důležitá, já chci dělat s dětma, a ne s nimi něco řešit. 
Zdá se tedy, že učitelé nejsou zcela připraveni a ochotni věnovat tak velký prostor rodičům svých žáků. Setkáváme s rozporem, poněvadž učitelé tvrdí, že nejdůležitější je komunikace s rodiči a naklonění si rodičů, a na druhé straně nemají dostatek chuti s rodiči aktivně komunikovat a brání se tím, že jsou tu především pro děti. Najít vhodnou míru a rozsah komunikace je často otázkou vzájemných hranic. Sem spadají i otázky častých schůzek s rodiči, e-mailové komunikace po pracovní době a sdělování osobního telefonního čísla.

\subsection{Obsah a smĕr komunikace}

Dalším potenciálně stresujícím aspektem komunikace je nevhodná kumulace jejího obsahu (ve smyslu věcnosti či emocionálnosti) a směru (iniciovaná školou či iniciovaná rodiči).

Jsou určité druhy komunikace, které učitelům vyhovují a o nichž ve skutečnosti mluví, když zdůrazňují potřebu spolupráce a komunikace s rodiči. Jedná se o komunikaci, kterou pro účely této studie označujeme za komunikaci na bázi předávání informací (např. kdy se jede na výlet, kolik je potřeba zaplatit peněz, kdy jsou třídní schůzky, co je za úkol na př́ští týden apod.).

Z uvedených př́kladů vyplývá, že se jedná o běžnou komunikační rutinu, kterou učitelé i rodiče žáků ve škole očekávají, protože patří ke školnímu prostředí. Tato komunikace je důležitá a učitelé počítají s tím, že je součástí jejich pracovní náplně. Také je to komunikace iniciovaná především ze strany školy. Jedná se o fakta a informace, které také mohou být předmětem sporu, nicméně většinou se nestanou tak ohrožující jako druhý typ komunikace komunikace na bázi emocí.

Druhý typ komunikace - komunikace na bázi emocí iniciovaná ze strany rodiče - je často vnímán jako stresující. Pod tímto označením se ukrývá mnoho různých komunikačních výměn, které jsou typické tím, že působí na emoce učitele, vyvádí ho z rovnováhy a nutí ho bránit svou profesionalitu či pochybovat o svých kompetencích apod. Většinou jsou charakteristické tím, že dokáží působit na citlivá místa učitele a zranit ho. Velmi zraňující se stává komunikace v okamžiku, kdy rodiče zpochybňují rozhodnutí učitele nebo vidí chybu z jeho strany (nejčastěji v oblasti výuky a hodnocení žáků). Učitelé cítí velký tlak ze strany rodičů, kteří je nutí obhajovat svá stanoviska a vysvětlovat, proč dali dítěti poznámku, napomenutí, důtku apod.: 
No víte co, já si myslím, že dneska bohužel není škola úplně takový to podnětný prostředí pro to jako, aby se člověk rozvíjel a měl snahu něco dělat, protože máte takový tlak ze tří stran, od dětí, od vedení a od rodičů (...) Prostě kluk zlobí a vy se musíte zpovídat matce, proč jako jste mu dala ty poznámky (...) Řekla bych nekritičtí rodiče vůči svým dětem.

Problematicky je vnímáno, když se vidění dítěte očima rodiče a učitele výrazně rozchází:

Oni místo toho, aby řekli dítěti, no tak se předved', jak to uděláš lepší, tak to prostě zpochybňují a přijdou nám vysvětlovat, že jsme se museli splést... $70 \%$ rodičů reaguje [na výchovné opatření] tím, že s tím jako nějak úplně nesouhlasí, má proti tomu nějaký výhrady.

Učitelům obecně velmi vadí, že nejsou pro rodiče již tak velkou autoritou jako v dřivějších dobách. Pocit'ují oslabení své pozice ve škole a krizi své autority vưči dětem i rodičům:

Dřív byl přeci jenom učitel někdo, rodiče si netroufli. Když už byli pozvaní do školy, věděli, že je průser, nikdo se s vámi nehádal. Dneska je to obráceně, kohokoli pozvete do školy, už je na to připravený, už je v opozici.

Někteří rodiče svými výhradami vlastně nepřímo (někdy i přímo) kritizují učitelské kompetence, zpochybňují učitelovu profesionalitu a schopnosti a sami se staví do role expertů, kteří učitelům chtějí radit, jak mají dělat svou práci. Pro učitele je tento „útok“ na jejich profesní čest výrazným zdrojem emoční nepohody a stresu, jak ukazuje následující výrok: „A co dětem? Rodičům. My musíme vycházet vstříc rodičům. A kdejaký rodič líp učí... No, možná ano." Snaha rodičủ kontrolovat, jak učitel učí, působí ohrožujícím dojmem. Učitelé říkají, že se necítí dobře, a to i ve chvíli, kdy si jsou jisti, že udělali pro dítě maximum a nepochybili. Jak se cítí v případě, pokud tuší, že možná mohli udělat něco lépe, o tom se můžeme jen dohadovat.

\subsection{Nerovnost sil v komunikaci}

Třetím aspektem je komunikace přímá versus komunikace oklikou přes vedení školy či instituce typu pedagogicko-psychologická poradna či Česká školní inspekce. Učitelé hovoří o zdroji stresu plynoucím z nerovnováhy sil, kdy je rodičovská strana mocně podporována právě oficiálními institucemi. Učitel, který podporu nevnímá, cítí ohrožení. 
Učitelé popisují jako zdroj stresu zažívanou bezmoc a nerovnost sil. Rodič se chová jako klient objednávající si službu s požadavkem ji kontrolovat, zároveň je posílen zprávami od odborníků ( $\mathrm{v}$ případě dětí se speciálními vzdělávacími potřebami) a institutem ČŠI. V některých př́padech je moc rodiče posílena ještě vedením školy, které se svého učitele nezastane.

Stres s sebou přinášejí doporučení ze školních poradenských zařízení, o která se rodiče opírají. Jeho možný efekt na učitele ilustruje následující výpověd':

Jste pořád prostě ve stresu. Že přijdou děti, který mají IVPéčka, který jsou z PPP a rodiče se prostě chrání, že má na to papíry, a ted' vás poučují. Tohle může, tohle nemůže, a pak jsou někdy až nepř́ijemný.

Poradna je jedna z možných autorit, na kterou se rodiče odvolávají. Z pohledu učitelů je to vyšší instance, kterou považuje většina rodičů za svého spojence proti učitelům. Pro učitele je náročné, když se musí neustále obhajovat a zodpovídat rodičům. Čím častěji k takovým konfliktům dochází, tím více je učitel ve stresu a časem se může objevit neochota s rodičem vůbec komunikovat. Každá další komunikace může učitele zraňovat, a ten se po čase začne bránit tím, že se komunikaci vyhne nebo bude vůči rodičům nepř́ijemný.

Zatěžující jsou nejen rodiče, kteří si stěžují přímo učiteli, ale také ti, kteří učitele tzv. obejdou a stěžují si př́mo řediteli jakožto nadřízenému učitele:

Jsou rodiče, co třeba prostě okamžitě jdou za ředitelem, napíší hned řediteli... Zrovna dneska jsme zase řešili takovou drobnost, a přitom ten ředitel a ten výchovný poradce... No stejně se to musí vrátit k tomu učiteli.

Záleží samozřejmě na řediteli, jak se v takové situaci zachová a zda svého kantora podpoří. Jsou ředitelé, kteří se svých pedagogů zastanou, a učitelé si tento zásah pochvalují. Někteří učitelé naopak nelibě nesou to, že ředitel se snaží spor s rodičem urovnat tak, že „uchlácholí“ rodiče či mu dá za pravdu, a to jen proto, aby se vše v klidu a co nejrychleji vyřešilo. Není pochyb o tom, že ředitelé jsou při komunikaci s rodiči $v$ ještě složitější situaci než sami učitelé. Někteří učitelé si zase přejí, aby je před problematickým rodičem ředitel chránil jako štít:

Já jsem třeba zažila školu, kde ředitel vůbec nepouštěl rodiče, když si přišli stěžovat, vůbec je nepouštěl $\mathrm{k}$ učitelům, vyřešil si to sám, v $90 \%$ př́padů se těch lidí zastal (...) bylo to oboustranně př́íjemný. 
Někteří rodiče tlak stupňují a obrací se přímo na školní inspekci. Inspekce bývá pro školy velkým „strašákem“ a rodiče jsou si toho pravděpodobně vědomi. Samotní učitelé mají z inspekce obavy, protože se jedná o orgán, který má právo kontrolovat a posuzovat, jak kvalitně odvádějí svoji práci. Někteří učitelé považují inspekci za „prodlouženou ruku rodičůu, která po jejich stížnostech může tvrdě udeřit na školu. To dokládají následující výroky:

Kolegyně měla nějaký spory s rodiči, tak na nás došla školní inspekce, že se kontrolovalo, jestli je všechno $\mathrm{v}$ pořádku (...) Ale prostě je to takový to nepochopení v dnešní době, že si každý myslí, což je můj názor, že na všechno mám právo a všechno můžu.

Svá specifika pak má také tendence rodičů se propojovat a jednat skupinově.

Šest rodičů nebo sedm matek si vždycky dá kafe a pak si jdou na ni stěžovat. Si na ni šli stěžovat, že chce po dětech výzdobu třídy. Že to je její práce. Ty rodiče jsou úplně šílení.

\section{5 „Rodič-prudič" jako koncentrát učitelského stresu}

In vivo pak vzniká termín rodič-prudič. Je to název pro rodiče, se kterým je komunikace nějakým způsobem problematická:

Tak v každé tř́idě se najde rodič, prudič, já bych řekla, že to je prostě stoprocentní, že opravdu v každé tř́dě je někdo takový, kdo neustále hledá chyby, je nespokojený nebo nereaguje úplně rozumně.

Mezi jeho základní vlastnosti patří neustálé vyhledávání komunikačních výměn se školou. Může to být komunikace se samotným učitelem, jeho kolegy či přímo s vedením. V termínu rodič-prudič se násobí nevhodná míra, způsob, obsah i směr komunikace s nežádoucí podporou ze strany institucí (viz obrázek 2). Rodič-prudič je koncentrátem učitelského stresu.

Komunikace s takovým rodičem je časově a emocionálně náročná a bohužel v ní většinou není možné „zvítězit“. Zaznívají výpovědi o tom, že tito rodiče mají moc a že jsou tím největším problémem. Učitelé mají z rodičů-prudičủ strach, a to nejen proto, že útočí na jejich emoce, ale také proto, že jsou schopni ohrozit pověst a kariéru učitele nebo pověst celé školy:

Právě tady byla zrovna jedna maminka, taková komplikovaná, že podává trestní oznámení snad na každou školu, kde je to její dítě. 
Objevují se i rodiče vykazující vyšší míru agresivity či osobnostní patologie:

Tak poslední nepř́íjemné jednání mám, že na mě matka řvala, a ještě lezla na stůl, jako s normálním člověkem se vždycky domluvíte. Ale když vám přijde někdo takový, tak nemáte šanci. Mě maminka naučila, že bláznům se neodporuje, tak jsem té paní neodporovala, protože by mě tam zmydlila.

Jedním z popisovaných způsobů, jak se učitel může bránit tomuto velkému potenciálnímu ohrožení ze strany rodičůu, kteří se chovají neadekvátně či se obracejí na vyšší místa a instance, je tzv. „pojistit se“. Pojistkou je vše si zapisovat, nechat podepisovat, nejlépe mít na vše svědectví dalších osob. Následkem těchto aktivit je velké „papírování“, které zabere mnoho času. Učitel musí být ve střehu, nic neopomenout, vše zaevidovat:

Zabírá to hodně času. Řešit každou takovou hloupost přes e-mail. Člověk ten e-mail nenapíše za minutu, váží slova, to tak zabírá hodně času... Zasahuje to do soukromého života $v$ tom smyslu, že to člověk řeší doma, tu korespondenci, to mailování.

Tato pojistka však v sobě obsahuje určitou „stresovou past“. Rozsah administrativy se totiž opakovaně ukazuje jako jeden z významných stresorů v učitelské profesi. Navíc pokud administrativní aktivity přesahují rozsah běžné pracovní doby, jsou dalším zdrojem stresu. Stresory se tedy v takovém případě učitelům kumulují.

Obrazně shrnuto: nejvíce stresující představou pro učitele je rodič, který vyžaduje velmi častý a intenzivní kontakt, je velmi emocionální a útočný, píše dlouhé e-maily v noci, ohání se zprávou z PPP a za zády má Českou školní inspekci, a proto každé jednání s ním musí být písemně evidováno. Zásahy takového rodiče jsou vysoce stresující a odráží se na zdraví učitelů, mohou vést až k rozvoji syndromu vyhoření:

Je to psychická zátěž. A fakt se pak do té školy chodí hodně špatně. A pak hlavně pracuje žaludek, nervy, někdo to řeší tím, že hodně jí, někdo zase nejí, je mu špatně, takže to už je pak na tom dotyčným. Někdo to zvládne přes jídlo, někdo to zvládne tak, že se zhroutí. 


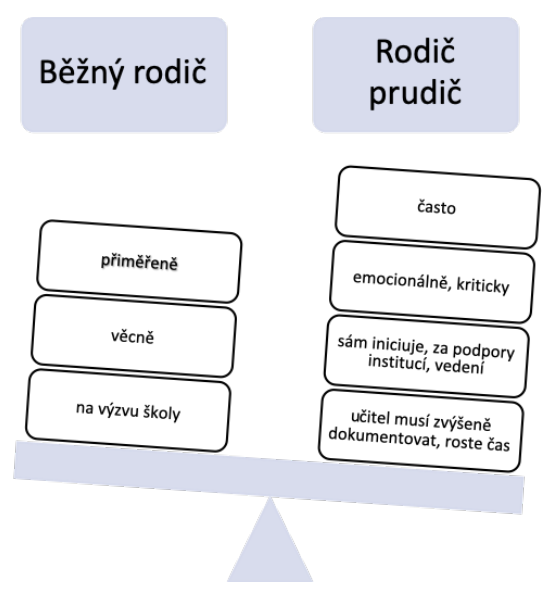

Obrázek 2. Rodič-prudič jako extrémní zdroj stresu učitele.

\section{Diskuse}

Není pochyb o tom, že učitelství je velmi stresující profese. Dokazuje to nepřeberné množství českých (Holeček, 2001; Urbanovská, 2011, aj.) i zahraničních výzkumů (Farber, 1982a; Lasky, 2000, aj.), uskutečněných v této oblasti v posledních desetiletích. Naše studie to potvrzuje také. Nabízí se otázka, zda to tak bylo vždy, nakolik se tato situace $v$ posledních letech proměnila a zda množství stresu v učitelské profesi přibývá.

Náš výzkum se zaměřil na rodiče a komunikaci s nimi jako významný zdroj stresu učitele. Na tuto výraznou interakční oblast rodič-učitel jako jeden z hlavních zdrojů stresu upozornil u nás již před 30 lety Mlčák (1999). Stresující jsou pro učitele náročná jednání s rodiči, rodičovské schůzky, nezájem rodičů o děti, neochota spolupracovat a př́lišná kritičnost rodičů vůči učiteli. Nedostatečná spolupráce s rodiči je výrazným zdrojem stresu učitelů nejen v našem výzkumu, ale umístila se také na 6. pozici ze 14 základních učitelských stresorů již u Paulíka (1998). K podobným závěrům dospěly také Štětovská a Sklaníková (2004). Šed’ová a Čiháček (Rabušicová et al., 2004) popisují typologii rodičů z hlediska četnosti komunikace, směru, počtu aktérů a symetrie komunikačního vztahu. Tato typologie se do značné míry podobá našemu zjištění, přičemž z hlediska stresového působení by našemu 
„rodiči-prudiči“ odpovídal rodič s klientským (dominantním) přístupem a zároveň snaživý (iniciující komunikaci).

Již Žídková a Martinková v roce 2003 popsaly, že se změnila náplň činnosti učitelů a zvýšily se nároky na jejich sociální interakce. I náš výzkum, realizovaný o 14 let později, ukazuje na podobný trend. Do centra pozornosti se dostala složka edukační a zvýšily se nároky na sociální interakci učitele.

Také Holeček (2001) upozornil ve svém výzkumu na rodiče s nekritickým přístupem ke svým dětem, kteří jsou agresivní a vyhrožují učitelům policií, soudy, inspekcí apod. I někteří učitelé v našem výzkumu mají podobnou zkušenost.

Zarážející je přetrvávající nepřipravenost učitelů na komunikaci s rodiči, a zejména na rodičovské emoce. Učitel je odborníkem na své předměty, je odborníkem na dítě, nicméně ukazuje se, že není schopen porozumět rodičovské perspektivě. Je s podivem, že tato situace stále trvá, přestože již bylo realizováno mnoho výzkumů, které se vztahem rodiny a školy a jeho vývojem v posledních desetiletích zabývají (Pohnětalová, 2015; Rabušicová et al., 2004; Štech \& Viktorová 1992, 2001). Učitelé studují a připravují se na výkon učitelské profese, nicméně nestudují dovednost komunikovat s rodiči, reagovat na krizovou situaci nebo umět si udržet dostatečný nadhled v př́padě kritiky ze strany rodičů, vedení nebo institucí. Komplikovanost vztahu rodiny a školy byla popisována již v minulosti. Trnková (Rabušicová et al., 2004) popisuje vyšší potřebu spolupráce s rodiči jako nový požadavek na učitele, zdá se však, že ani po 15 letech od vydání jejího textu, v roce 2019, učitelé komunikaci s rodiči neberou jako rovnocennou součást své profese.

Současným trendem je posun od sumativního k formativnímu hodnocení. Ve výzkumu se ukázalo, že učitelé nejsou připraveni na kritiku veřejnosti. Téměř každou kritiku si vykládají jako útok na svou profesionalitu. Chybí jim dostatečný náhled a sebereflexe. Učitel se nesmí bát svého selhání, ale naopak by měl být podporován, aby na své sebereflexi pracoval, neodmítal supervizi a byl ochotný vstoupit do otevřené diskuze.

Velkým tématem je nedůvěra a neporozumění mezi učitelem a rodičem, kdy rodič tvrdí, že dítě se doma chová jinak a obtíže s ním nejsou („doma to nedělá, doma tohle chování nevidím“). Rodič se domnívá, že chyba je v učiteli nebo že je na učiteli, aby žáka ve škole přinutil k práci a poslušnosti. Rodiče si často neuvědomují, že škola a rodina jsou jiná prostředí, ve kterých se dítě chová odlišně. Učitel má ve třídě na starosti více žákủ a je v jiné situaci než 
rodiče doma, kde mají jen jedno nebo několik dětí. Učitelé se naopak odvolávají na nevychovanost dítěte z rodiny, se kterou učitel ve tř́́dě již nic udělat nemůže. Naše studie ukazuje, že učitel je sice vzdělaný profesionál, ale zdá se, že rozdíly mezi rodinnou a školní socializací vnímá jako téma, které bylo sice součástí jeho státní zkoušky, ale v praxi jej př́liš nevyužívá. Nereflektuje rozdílné cíle obou institucí. Chápe a hájí zejména cíle školy.

Autorita učitele prošla v posledním století obrovskou proměnou od výrazné autoritativní postavy s právem trestat děti i rákoskou až po současného učitele, klienta rodičů, který žije v neustálém strachu z toho, že jeho schopnosti a dovednosti budou zpochybněny a on se bude muset obhajovat rodičům, vedení či institucím. Současný učitel se nachází pod tlakem z mnoha stran. To potvrzuje i naše studie.

Navýšení stresorů v učitelské profesi má souvislost také s navýšením administrativní zátěže, která je jedním z velmi výrazných stresorů (Mlčák, 1999). Podle výzkumu (Paulík, 1998) je podřizování se učitelů administrativě, se kterou často nesouhlasí, třetím nejdůležitějším zátěžovým faktorem. Učitelé mají pocit, že administrativa je nadbytečná, dostává je do časové tísně, a to vede k pracovnímu přetížení (Holeček, 2011). Výsledky našeho šetření jsou ve shodě s těmito zjištěními. Za jednu z podob administrativní zátěže lze považovat velmi četnou e-mailovou a telefonickou komunikaci s rodiči. Dalším typem administrativní zátěže je nutnost vše evidovat a zapisovat pro případnou kontrolu ze strany ČŠI. Administrativu navyšují také zprávy z poradenských zařízení, nutnost reagovat na doporučení odborníků, vypracovat IVP apod. S touto administrativou se pojí velký strach a úzkost učitele z budoucnosti. Učitel již předvídá, že v budoucnu se objeví stížnost, a on bude muset prokazovat, že ve své práci nepochybil. Tento anticipující strach či úzkost učitele nikdy neopouští a je dalším zdrojem permanentního stresu.

Závěrem lze shrnout, že stres u učitelů, ačkoliv byl součástí tohoto povolání vždy, prochází v posledních letech proměnou. Na učitele je kladeno více požadavků v podobě navýšení administrativy a komunikační zátěže. Obojí vede $k$ větší časové zátěži a nárůstu stresu u učitelů. Změny však nejsou tak masivní, jak bychom očekávali. Většina námi popisovaných stresorů v komunikaci s rodiči se objevuje již ve studiích publikovaných po roce 1990, v posledních letech se jedná spíše o kumulaci jevů a jejich prohlubování. Rodič je klientem a zároveň je sám aktivní, stále roste informovanost laické veřejnosti a s tím souvisí i vyšší nároky na školu. Sociální sítě a elektronická komunikace 
přinášejí rychlejší tok informací, ale žádají též jasné stanovení hranic. Pocit nerovnosti sil ve smyslu posílení rodičovské veřejnosti (s oporou v ČŠI a dalších institucích) oproti škole, která musí přijmout a pečovat o každé spádové dítě, po roce 2016 se zaváděnou inkluzí zřejmě sílí, ale pro toto tvrzení nemáme žádné kvantifikované podklady.

\section{$5 \quad$ Praktická doporučení}

Bylo by vhodné reflektovat tyto změny a umožnit učitelům, aby se na své povolání mohli připravit po všech stránkách. Rovněž následná možnost profesního rozvoje a psychohygieny formou strukturovaného sdílení či supervize by neměla být opomíjena, pokud chceme, aby učitelé ze škol neodcházeli a naše děti a budoucí generace byly vzdělávány kvalitními (tj. méně stresovanými a pokud možno nevyhořelými) pedagogy a pedagožkami.

Na závěr si proto dovolujeme formulovat následující výzvy, praktická doporučení:

- Domníváme se, že je potřeba klást již v pregraduálním studiu větší důraz na výuku učitelů v tématu vztahu rodiny a školy, aby si učitel uvědomoval, že rodina i škola mají do jisté míry odlišné cíle, což je v pořádku a není v tom nic osobního proti učiteli. Výzkumy tato fakta prezentují dlouhodobě, ale učitelé si je neuvědomují.

- Dále věříme, že by obsahem studia měla být př́íprava učitelů na komunikaci s dospělými a komunikaci $\mathrm{v}$ emocionálně náročných situacích, event. příprava na třídnictví (kde učitel řeší komunikačních potíží nejvíce). Návody pro dobrou komunikaci rodiny a školy ve své brožuře Rodiče - nečekaní spojenci přináší např. vzdělávací program Varianty (Felcmanová, 2013).

- Zvyšování self-efficacy učitelů, posilování profesní sebedůvěry učitele jako kompetentního státního zaměstnance je jedním z preventivních faktorů vyhoření učitelů. Učitelství není poslání, je to zaměstnání. Této perspektivě může přispívat jednak lepší finanční ohodnocení učitelů, jednak kvalitní supervize zaváděná do škol. Zavedení supervize do škol chápeme jako možnost profesionálního sdílení a reflexe prožívaných emocí. Zároveň je supervize nástrojem zkvalitňování týmové spolupráce, zvyšování sebereflexe včetně práce s vlastní chybou a reflexe užívaných copingových strategií. 
- V neposlední řadě se nabízí vyřešení otázky, kam se může obrátit učitel při konfliktu s rodičem, která instituce stojí po boku školy v případném sporu s rodinou.

Na úplný závěr bychom rádi poznamenali, že naše studie nepopisuje vztah rodiny a školy $v$ jeho komplexnosti, zaměřuje se pouze na úzkou výseč učitelského stresu. I přes daná zjištění věříme, že škola s rodinou a rodina se školou mohou komunikovat kvalitně a ku prospěchu dítěte/žáka, což by se dalo dokumentovat mnohými příklady dobré praxe.

Rádi bychom tímto poděkovali anonymním recenzentům, kteří $\mathrm{k}$ nám byli přísní, ale svými postř̌ehy a doporučeními výrazně přispěli ke zvýšení kvality tohoto textu. S pokorou děkujeme.

\section{Literatura}

Boyatzis, R. E. (1998). Transforming qualitative information: Thematic analysis and code development. Thousand Oaks: Sage Publications.

Brackett, M. A., Palomera, R., Mojsa Kaja, J., Reyes, M. R., \& Salovey, P. (2010). Emotion-regulation ability, burnout, and job satisfaction among British secondary-school teachers. Psychology in the Schools, 47(4), 406-419.

Braun, V., \& Clarke, V. (2006). Using thematic analysis in psychology. Qualitative research in psychology, 32, 77-101.

Farber, B. A. (1982a). Teacher burnout: assumptions, myths, and issues. New York: Teachers College, Columbia University.

Farber, B. A. (1982b). Stress and burnout: implications for teacher motivation. Paper presented at the Annual meeting of the American educational research association, New York: Teachers College, Columbia University.

Felcmanová, A. (2013). Rodiče - nečekaní spojenci: jak rozvíjet partnerský dialog mezi školou a rodinou. Praha: Člověk v tísni.

Fink, G. (2010). Stress Science: Neuroendocrinology. Amsterdam; Boston: Academic Press.

Hargreaves, A., \& Lasky, S. (2004). The parent gap: The emotional geographies of teacher-parent relationships. In F. Hernandez \& I. F. Goodson (Eds.), Social geographies of educational change. (s. 103-122). Springer: Dordrecht.

Holeček, V., Jiřincová, B., \& Miňhová, J. (2001). Faktory ohrožení osobnosti učitele. In E. Řehulka \& O. Řehulková (Eds.), Učitelé a zdraví 3 (s. 51-57). Brno: Pavel Křepela.

Kebza, V., \& Šolcová, I. (2008). Hlavní koncepce psychické odolnosti. Československá psychologie, 52(1), 1.

Keyes, C. R. (2002). A way of thinking about parent/teacher partnerships for teachers. International Journal of Early Years Education, 10(3), 177-191.

Kohoutek, R., \& Řehulka, E. (2011) Stresory učitelů základních a středních škol v České republice (zejména stresory způsobené učitelům žáky). In E. Řehulka (Ed.), Škola a zdraví pro 21. století (s. 105-117). Brno: Masarykova univerzita.

Křivohlavý, J. (1994). Jak zvládat stres. Praha: Grada Avicenum. 
Kyriacou, Ch. (2004). Klíčové dovednosti učitele: cesty k lepšímu vyučování. Praha: Portál.

Lasky S. (2000). The cultural and emotional politics of teacher-parent interactions. Teaching and Teacher Education, 16(8), 843-860.

Marek, T., Schaufeli, W. B., \& Maslach, C. (2017). Professional burnout: Recent developments in theory and research. New York: Routledge.

Maslach, C., Jackson, S. E., \& Leiter, M. P. (1996). Maslach burnout inventory manual. Palo Alto Consulting Psychologists Press.

Mlčák, Z. (1999). K teoretickému a výzkumnému paradigmatu psychické, zátěže učitelů. In E. Řehulka \& O. Řehulková (Eds.), Učitelé a zdraví 2 (s. 107-121). Brno: Pavel Křepela.

Paulík, K. (1998). Co obtěžuje učitele různých typů škol. In E. Řehulka \& O. Řehulková (Eds.), Učitelé a zdraví 1 (s. 35-40). Brno: Psychologický ústav (Akademie věd ČR).

Plichtová, J. (1996). Obsahová analýza a jej možnosti využitia v psychológii. Československá Psychologie, 40(4), 304-314.

Pohnětalová, Y. (2015). Vztahy školy a rodiny: př́ipadové studie. Hradec Králové: Gaudeamus.

Ptáček, R., Vňuková, M., Raboch, J., Smetáčková, I., Harsa, P., \& Švandová, L. (2018). Syndrom vyhoření a životní styl učitelů českých základních škol. Česká a Slovenská psychiatrie, 114(5), 199-204.

Rabušicová, M., Šed’ová, K., Trnková, K., \& Čiháček, V. (2004). Škola a (versus) rodina. Brno: Masarykova univerzita.

Selye, H. (1966). Život a stres. Bratislava: Obzor.

Shirom, A., \& Melamed, S. (2006). A comparison of the construct validity of two burnout measures in two groups of professionals. International Journal of Stress Management, 13(2), 176-189.

Smetáčková, I., Viktorová, I. Pavlas Martanová, V., Štech, S., \& Ptáček, R. (2018, v tisku). Vztah syndromu vyhoření, copingových strategií a self-efficacy mezi vyučujícími na českých základních školách. Československá psychologie.

Smetáčková, I., Vondrová, E., \& Topková, P. (2017). Zvládání stresu a syndrom vyhoření u učitelek a učitelů ZŠ. E-Pedagogicum, I, 59-75.

Strauss, A. L., \& Corbin, J. (1999). Základy kvalitativního výzkumu: postupy a techniky metody zakotvené teorie. Boskovice: Albert.

Štech, S., \& Viktorová, I. (1992). Rodičovské pohledy na školu a vztah dětí k ní. In Pražská skupina školní etnografie, Co se v mládí naučíš... (s. 144-163). Praha: PedF UK.

Štech, S., \& Viktorová, I. (2001). Vztah rodiny a školy - hledání dialogu. In Z. Kolláriková \& B. Pupala (Eds.), Předškolní a primární pedagogika (s. 57-94). Praha: Portál.

Štětovská, I., \& Skalníková, M. (2004). Sociální opora v kontextu proměn role učitele. In A. Vališová, M. Rymeš, \& K. Riegel (Eds.), Rozvoj české společnosti v Evropské unii IV (s. 105-119). Praha: Matfyzpress.

Urbanovská, E., \& Kusák, P. (2005). Syndrom vyhoření ve vztahu k vnímání pracovní zátěže. In E. Řehulka (Ed.), Psychologické otázky výchovy, vzdělávání a poradenství (s. 101-115). Olomouc: PedF UP.

Urbanovská, E. (2011). Profesní stresory učitelů a syndrom vyhoření. In E. Řehulka (Ed.), Škola a zdraví 21: Výchova ke zdravotní gramotnosti (s. 309-322). Brno: Munipress.

Židková, Z., \& Martinková, J. (2003). Psychická zátěž učitelů základních škol. České pracovní lékařství, 3, 6-10. 


\title{
Autoři
}

Mgr. PhDr. Veronika Pavlas Martanová, Ph.D., Univerzita Karlova, Pedagogická fakulta, Katedra psychologie, Myslíkova 7, 11000 Praha 1, e-mail: Veronika.pavlas.martanova@gmail.com

Mgr. et. Mgr. Olga Konůpková, ZŠ Vladislava Vančury, Praha-Zbraslav, Hauptova 591, 15600 Praha-Zbraslav, e-mail: olga.konupkova@zs-zbraslav.cz

\section{Different worlds of teachers and parents: Interaction with parents as a source of teacher's stress}

\begin{abstract}
The purpose of the study is to describe the factors identified by primary school teachers as a source of stress in contact with parents.

Structure: In the first part, research activities in the area of teacher stress in recent decades are maped. The second part deals with research methodology - thematic analysis of data and description of sample respondents (45 interviews from 12 primary schools). The third part presents the results of the survey, the fourth part deals with the discussion and the fifth part with the practical recommendations.

Findings: On the background of the theory is the teacher's causality of the child's problems (teacher blames parents for child problems as a defense mechanism against frustration and stress). The central category of the source of stress is mutual communication and some of its aspects: the frequency of communication, its content and direction, the balance of communication power and its documentation. Then, in vivo, the term "Annoying parent - ranger" arises, in which inappropriate frequency (too often), content (emotionally and critically) as well as the direction of communication (from parent to school) are multiplied with unwanted support from institutions and the needs to document everything. "Annoying parent - ranger" is a concentrate of teacher stress.

Conclusions: Most of the stressors described in communication with parents appear in studies published after the year 2000, it is rather a cumulation of phenomena and their deepening, what we discovered. Practical recommendations are formulated: themes related to family and school and communication in stress situations for undergraduate studies, introducing supervision into schools and systemic support for teachers.
\end{abstract}

Key words: teacher, stress, communication with parents, burn-out syndrome 